\title{
A dialogue with Europe - regarding Spanish Prisons
}

\author{
Elena Larrauri ${ }^{1}$ \\ Professor of Criminal Law and Criminology, \\ Universitat Pompeu Fabra, Barcelona, Spain
}

I am aware that Sonja Snacken is sometimes critical of the EU, especially regarding crime control and immigration policies. As she wrote to me in an e-mail '(...) it was not until the Aranyosi and Căldăraru case of 2016 that the European Court of Justice stated that the principle of mutual recognition within the EU is subordinated to the respect for fundamental rights, finally following the ECtHR case-law.' And notwithstanding, to me, 'Sonja is Europe', or at least the Council of Europe! In prisons and human rights, she is unavoidably entangled with the influence in Spain of what we call 'Europe'. I will try to show this with three examples.

\section{Spanish criminology meets 'Europe' in 2000 at the ESC}

I met Sonja thanks to the ESC of which she had been the president (2004). Coming from 'critical criminology', I shared, I think, an initial distrust when gathering with 'administrative criminology'. Knowing Sonja helped to convince me of a 'self-evident truth': that the majority of criminologists are liberals, and that the differences among us are infinitely much less, than

1 The author thanks, especially, professors Borja Mapelli, Esther Pascual and Alex Saiz-Arnaiz for their comments. And, as always, Andrew Henley for improving my text. This paper has benefited from the support of 'Ejecución y supervisión de la pena: Calidad de la intervención, legitimidad y reincidencia» financiado por MINECO (Ref. DER2015-64403-P), FEDER, UE; and 'Redes de Excelencia': Desarrollo de un modelo criminológico y empírico de la política criminal - Acrónimo EmpiriC -. Financiado por MCIU-AEI (Ref. DER2017-90552-REDT). 
all our commonalities. In addition, she is also an excellent example of how scientific research can contribute to policy recommendations ${ }^{2}$.

Sonja also got the ESC prize in Porto (2015), and I recall her words. Her discourse was a remembrance of the people that had helped her in her career. Not of what she had achieved, but thanks to those who had made her achievements possible.

A third moment was when we were sitting together in a session and listening to some young criminologists in Cardiff (2017). She told me that she was going to retire soon, and that she was happy because she could already see new generations following the work she had done in the areas of prison law, human rights, and prison supervision. I remember being surprised by this announcement, but slowly since then, I have also convinced myself that we can retire when we secure continuity of lines of thought.

And last, I had the privilege of interviewing her in Ghent (2019) for the ESC Oral History of Criminology. Kristel Beyens had broken her ankle and there was concern that the interview might have to be suspended. Even if I am not the biggest expert in Sonja's work, I thought I could manage. The interview became a lesson, filled with vital optimism³ ${ }^{3}$.

In the end, the ESC is its members. To meet and listen to professors like Sonja Snacken has done a great deal to allow comparative work, search for better practices and to stimulate research that tries to speak to a broader community than the one in our own countries. And this has forced us Spanish criminologists to discover the European soft law and the judgments of the European Court of Human Rights (ECtHR).

\section{The influence of the Council of Europe in Penology}

In addition to personal encounters at the ESC, Sonja was also relevant in bringing the influence of European penology closer to academic criminology.

Spain entered the Council of Europe in 1977 after Franco's death (1975) but it is probably true that the knowledge of 'European soft law' regarding penal systems was not influential in criminology until $2000^{4}$. Slowly, this

2 For a broader explanation, watch Snacken (2019) European Criminology Oral History Project.

3 That Sonja Snacken is (and remains) an optimist can also be seen in her paper Resisting Punivitiness in Europe? (2010). On a personal note, I smiled because I had written in Spanish a similar title: Punitive Populism... and how to resist it (Larrauri, 2006).

4 For example, we published a book on Alternatives to Imprisonment (Cid and Larrauri, 
began to change, new generations of scholars began to travel abroad, the impact of the ESC, Undergraduate Degrees in Criminology began in 2009, the Erasmus students, SPACE -the Council of Europe Annual Penal Statistics, and the possibility of comparative studies with colleagues. All these developments certainly helped to construct Europe 'from below'.

To navigate all of the European organizations and texts is not easy ${ }^{5}$. I invited Sonja Snacken to give a lecture to our Masters students, also as an excuse to familiarize myself with all this European framework. Sonja accepted our invitation and came to lecture on the Master of Criminology course in Barcelona in 2010. Her combination of legal analysis and empirical research was exactly what we needed!

This nice professor began to mention a 'soup of letters' that I quickly had to learn. In effect, as it is known Sonja was the chair (2006-2012) of the Council for Penological Cooperation (PC-CP). The PC-CP provides the standards and recommendations that are later approved by the Council of Europe on matters on prisons and community sanctions and measures and set the normative framework in terms of human rights that are afterwards influential to each country. These recommendations were known in Spain, and they did set a landmark on how to judge our own systems ${ }^{6}$.

Especially regarding the establishment of alternatives to prison which was accomplished in Spain with the new penal code, labeled 'the penal code of democracy' in 1995. Franco's death gave the opportunity to reform - in substantial ways - the old criminal code and the new one had as its main accomplishments the introduction of alternatives to prison. In 1995 Spain introduced the system of day-fines, and community service and increased the possibilities of suspended sentences and probation.

It is not only that the law introduced these community sanctions, but that there was a cultural milieu considering prison as a last resort, and in favour of using them, which pressured the administration to put them into practice (Blay and Larrauri, 2015). Certainly, this cultural milieu was also due to the German penal reform (Alternativentwurf eines Strafgesetzbuches) which has always been so influential among Spanish criminal law professors ${ }^{7}$. And the option for a reductionist policy was no doubt increased by the works of other

1997) and there is no mention of any European Recommendation, and I don't think we were the only ones to make this oversight.

5 Fortunately, to provide context and some semblance of order to all this knowledge, 'the bible' soon came along: Principles of European Prison Law and Policy, written by Dirk van Zyl Smit and Sonja Snacken.

6 See for example Cid (2010).

7 Larrauri (2001) 
academics like Sonja Snacken (2006), who considered this policy a landmark of European Legal and Political Culture.

\section{The influence of the Council of Europe in Spanish Prisons}

I will briefly describe the influence of the European Prison Rules, the ECtHR and the CPT in Spain.

\section{European Prison Rules and the Spanish Penitentiary Law}

Spain had a humanist tradition regarding prison law (since the Ordenanza General de los Presidios del Reino, de 1834). This had been interrupted with the Civil War and the dictatorship that caused a tremendous increase in prison numbers due to the imprisonment of all the political opposition. During almost 40 years, prison warden positions were given to ex-military personnel, who implemented an authoritarian regime based on order and discipline inside prison (García-Valdes, 2019).

Let it be known to our European colleagues, that the Penitentiary Law was the first law approved by the democratic parliament in 1979 (and by unanimity: 284 votes in favor, and two abstentions, García Valdes, 2019) ${ }^{8}$. It is no wonder, since many of the newly elected members were especially sensitive to matters of imprisonment, because they had either suffered it, or had close knowledge of it.

According to its main author, a Spanish criminal law professor, the Penitentiary Law had as its main influence the European Prison Rules (EPR) of 1973 and also other penitentiary laws of countries like Sweden, Italy and Germany (García-Valdes, 2019).

I asked one academic who directly participated in these reforms ${ }^{9}$ in which areas they could specifically detect the influence of the EPR. The answer (which will please Sonja Snacken) was: in the idea of the prisoner as a person, as a human being, and as a bearer of rights (Rechtssubject).

8 It was actually the first 'organic' law, a special category of law which requires absolute majority because it deals with human rights.

9 Borja Mapelli (Professor of Criminal Law, personal communication) participated in the reform of the Reglamento 1996. This represented a shift from a very psychological view of rehabilitation based on treatment, to a wider view of reintegration that included other activities like education, occupation, and contact with the outside world. 
The Penitentiary Law tries to protect the dignity of the person and recognizes the right of the prisoner to be called by his name, to wear his clothes, to occupy a single cell, to receive a salary for the work done inside prison, the right to medical assistance, the right to refuse participation in treatment activities, and the prohibition of punishment cells.

The Spanish Constitution states that the deprivation of freedom must be oriented to rehabilitation and that the prisoner retains all his rights, not affected by the sentence, the law or the finality of the punishment ${ }^{10}$. The Penitentiary Law states the same and adds a concrete catalog of prisoners' rights $^{11}$. In addition to the recognition of prisoners' rights, the Penitentiary Law in Spain introduces 'due process', and 'procedural safeguards' (Carou, 2017).

Because of the time of the discussion of the Penitentiary Law in 1979, it is probably sensible to conclude that the ECtHR [Case of Golder v. The United Kingdom, Judgment 21 February 1975] and the famous dictum 'The Convention does not stop at the prison gate', also had an influence in the Spanish Prison Laws.

\section{The ECtHR and the Constitutional Court regarding Spanish prisons}

The Spanish Constitutional Court played an active role regarding prisoners' rights particularly until 2007 (Reviriego, 2008) ${ }^{12}$. Although it is probably also correct to conclude that its impact was more visible in procedural than in substantive rights, where it usually deferred to the prison administration (Livingstone and Owen, 1993; Scott, 2013).

What has been the influence of the ECtHR in Spain? Spain has never been found in violation of art. 3 of the ECHR (for torture or inhumane and degrading punishment) or any other concerning prison matters ${ }^{13}$. In addition, there is very little reception in the official institutions and

10 This last can be similar to the restrictions by 'necessary implication' (Lazarus, 2006).

11 Art.4 of the Reglamento Penitenciario, 1996.

12 It saw approximately 150-200 cases since 1980 regarding prison matters.

13 The cases in where there has been a violation of art.3 in its procedural aspect have been in police stations (Pascual, 2016). The closest recent one might be the Case of Cano Moya v Spain (Final Judgment 11/01/2017) '(...) the Court finds that the refusal of the post-sentencing judge to provide the applicant with photocopies of the complete case file amounted to a hindrance of the exercise of his right of individual petition. It follows that the State has failed to comply with its obligations under Article 34 of the Convention'. 
documents of the ECtHR judgments in Spain (Pascual, 2016) ${ }^{14}$. And, as we can see in the following table based on the Annual Report of the ECtHR (2018) very few cases reach the ECtHR, when I compare Spain with similar countries $^{15}$.

\begin{tabular}{|l|c|c|c|c|c|}
\hline 1959-2018 & $\begin{array}{c}\text { Total } \\
\text { Judgments }\end{array}$ & $\begin{array}{c}\text { At least one } \\
\text { violation }\end{array}$ & $\begin{array}{c}\text { No } \\
\text { violation }\end{array}$ & $\begin{array}{c}\text { Friendly } \\
\text { settlement }\end{array}$ & $\begin{array}{c}\text { Other } \\
\text { Judgments }\end{array}$ \\
\hline SPAIN & 167 & 112 & 48 & 3 & 4 \\
\hline FRANCE & 1,013 & 736 & 175 & 64 & 38 \\
\hline GERMANY & 340 & 195 & 117 & 13 & 15 \\
\hline ITALY & 2,396 & 1,830 & 69 & 355 & 142 \\
\hline U. K & 547 & 315 & 141 & 68 & 23 \\
\hline
\end{tabular}

Table 1: Number of cases that reach the European Court of Human Rights

What explains the scarce appeal to the ECtHR? According to research done by Pascual (personal communication) based on interviews in 10 prisons conducted with prisoners and other relevant actors, the main reasons are: i. prisoners get tired of appealing since they first have to go to the Constitutional Court (86 \%); ii. Lack of knowledge by lawyers (79\%) and prisoners (99\%) of the ECtHR; iii. Belief you need to have financial means (94\%).

In sum, the ECtHR regarding prisons has not been very influential. This might possibly change since the important case of Del Rio Prada v. Spain, 21 October 2013. Maybe this also has to do with the fact that until 2007 the Spanish Constitutional Court provided more relief ${ }^{16}$. It remains to be seen if the declining activity of the Constitutional Court promotes the number of appeals to the ECtHR, once the new generations of Spanish lawyers are better acquainted with its judgments.

14 In the official document (Jurisprudencia Penitenciaria) summarizing all judgments, Pascual reports in the last 25 years only three citations of the ECtHR (two on pretrial detention and one on the 'Parot doctrine'). See also Alcacer, Beladiez and Sanchez Tomás (2013).

15 Although these figures are not homogeneous. I thank Alex Saiz Arnaiz for pointing this out. Spain ratified the Convention in 1979, France in 1974, Germany in 1952, Italy in 1955 and UK in 1951.

16 A new law LO 6/2007 May 24th allows to reject appeals (recursos de amparo) if they do not have 'constitutional relevance'. Since 2008-2012 the average of admitted appeals has been 1,5\% per year. Before the rates could be $10-14 \%$ per year (Alex Saiz Arnaiz, personal communication). 


\section{The CPT and the Spanish Penitentiary Judge}

The introduction of a penitentiary judge (Juez de Vigilancia Penitenciaria) was due to the influence of the French and Italian system (García Valdes, 2019). In Spain, the supervision and monitoring of the prison has been trusted to a specific judge. Actually, this is considered as the most profound gain of the Penitentiary Law, the creation of a specific judge to monitor prisons. The administration was deemed to be both accused 'party' and 'judge' and unable to be impartial.

How do these specific judges supervise and monitor prison activity? They can visit the prisons and receive any complaints from the prisoners. However, there are very few Judges in all Spain (17 Judges for 71 prisons) ${ }^{17}$. On the other hand, there is an excess of paperwork. Surely this explains the charge leveled by the CPT on its visit to Spain (in its 2016 report): 'In terms of judicial supervision of the penitentiary system, the CPT observed once again that supervisory judges acted mainly as a 'rubber stamping authority' for the decisions of the prison administration rather than as an independent and impartial supervisory institution'.

Therefore, the work of the CPT (for which Sonja Snacken acted also as an expert for 15 years) is welcome. A recent paper of the results of the CPT last report (2016) when visiting Spain, concludes that $44 \%$ of the recommendations have been partially or totally accepted ${ }^{18}$.

Finally, it might be wise to explore the sanctioning mechanisms of the Administration in order to not only rely on judges (Larrauri, 2020). If the administrative system of complaints can be impartial, guarantee voice, include safeguards and be effective, I think this might be an argument in favour of promoting it, instead of blindly trusting that judicial supervision will always be preferable ${ }^{19}$.

There is always the danger when writing an academic paper that we describe a personal history and think that we are, as Cohen would wittingly put, recording a 'change of paradigm'. I hope that I have not made this mistake. And if I have, I have a good excuse: to render tribute to the work and life of Sonja Snacken.

17 In addition, there is no differentiation between the complaints that can be addressed to these judges. A judge has to respond the complaint of a prisoner not having cards to play and of a prisoner that has been for five days placed in mechanical fixation (Pascual, 2020, personal communication).

18 Of course, as the authors state, acceptance is not implementation (Aizpurua and Rogan, 2019)

19 I make this point in the discussion of prison leave (see Larrauri, 2020). 


\section{References}

Agudo, J. (2018). La función administrativa de control. Madrid: Civitas.

Aizpurua, E. and Rogan, M. (2019) La situación de las prisiones y los centros de menores en España: Analizando las observaciones del CPT Boletín Criminológico (n. ${ }^{\circ}$ 182) Artículo 1.

Alcacer, R. Beladiez, M. and Sanchez Tomas, J.M. (2013). Conflicto y dialogo con Europa. Las condenas a España del TEDH. Madrid, Civitas Thomson.

Blay, E. and Larrauri, E. (2015). Community punishments in Spain: A tale of two administrations. In G. Robinson, and F. McNeill. (eds.) Community Punishment. European perspectives (pp. 191-208) Abingdon, Routledge.

Carou, S. (2017) El principio de legalidad en el derecho penitenciario español. Indret, numero 4 (octubre).

Cid, J. and Larrauri, E. (1997) Alternativas a la prisión. Barcelona, Bosch.

Cid, J. (2010) La política criminal europea en materia de sanciones alternativas a la prisión y la realidad española: una brecha que debe superarse, Estudios Penales y Criminológicos, vol. XXX.

Garcia Valdes, C. (2019) 'Que cuarenta años no es nada': Derecho Penitenciario español, antecedentes y Ley General Penitenciaria. ADPCP, VOL. LXXII.

Larrauri, E. (2001) Aportación de las ciencias sociales a la elaboración de reformas en la legislación penal. Díez Ripollés, J.L. and Cerezo Domínguez, A.I. Los problemas de la investigación empírica en criminología: la situación española. Valencia, Tirant lo Blanch. p. 93-107.

Larrauri, E. (2006) Populismo punitivo y cómo resistirlo. Jueces para la democracia. (55), 15-22.

Larrauri, E. (2020) Reducing Discretion in the Administration of Prison Leave: In Search of Legitimacy. European Journal on Criminal Policy and Research, $1-16$.

Lazarus, L. (2006) Conceptions of Liberty Deprivation, Modern Law Review, 69 (5).

Livingstone, S., and Owen, T. (1993). Prison Law. Oxford, Clarendon Press.

Pascual, E. (2016) Análisis del sistema penitenciario español a la luz de la legislación europea y propuestas de mejora, Cuadernos Digitales de Formación, numero 2.

Reviriego, F. (2008). Los derechos de los reclusos en la jurisprudencia constitucional. Madrid, Universitas.

Scott, D. (2013) The Politics of Prisoner Legal Rights, The Howard Journal of Criminal Justice, 52(3), 233-250.

Snacken, S. (2006) A Reductionist Penal Policy and European Human Rights Standards. European Journal Criminal Policy and Research. 12 (2):143-164.

Snacken, S. (2010) Resisting punitiveness in Europe? Theoretical Criminology, 14(3), 273-292.

Snacken, S. and Dumortier, E. (2012) (Eds) Resisting punitiveness in Europe? Abingdon, Routledge.

van Zyl Smit, D. and Snacken, S. (2009) Principles of European Prison Law and Policy. Oxford, OUP. 